\title{
Nanoscopic Dynamics Dictate the Phase Separation Behavior of Intrinsically Disordered Proteins
}

\author{
Katharina Laaß, ${ }^{\dagger}$ Felipe García Quiroz, ${ }^{\ddagger}, \uparrow$ Johannes Hunold ${ }^{\dagger}$ Stefan Roberts, ${ }^{\ddagger}$ \\ Ashutosh Chilkoti, ${ }^{\ddagger}$ and Dariush Hinderberger ${ }^{*, \dagger}$ \\ $\dagger$ Institut für Chemie, Martin-Luther-Universität Halle-Wittenberg, Halle (Saale), Germany \\ $\ddagger$ Department of Biomedical Engineering, Duke University, Durham, USA \\ ФCurrent address: Wallace H. Coulter, Department of Biomedical Engineering, Georgia \\ Institute of Technology and Emory University, Atlanta, GA 30322, USA
}

E-mail: dariush.hinderberger@chemie.uni-halle.de 


\section{Supporting Information}
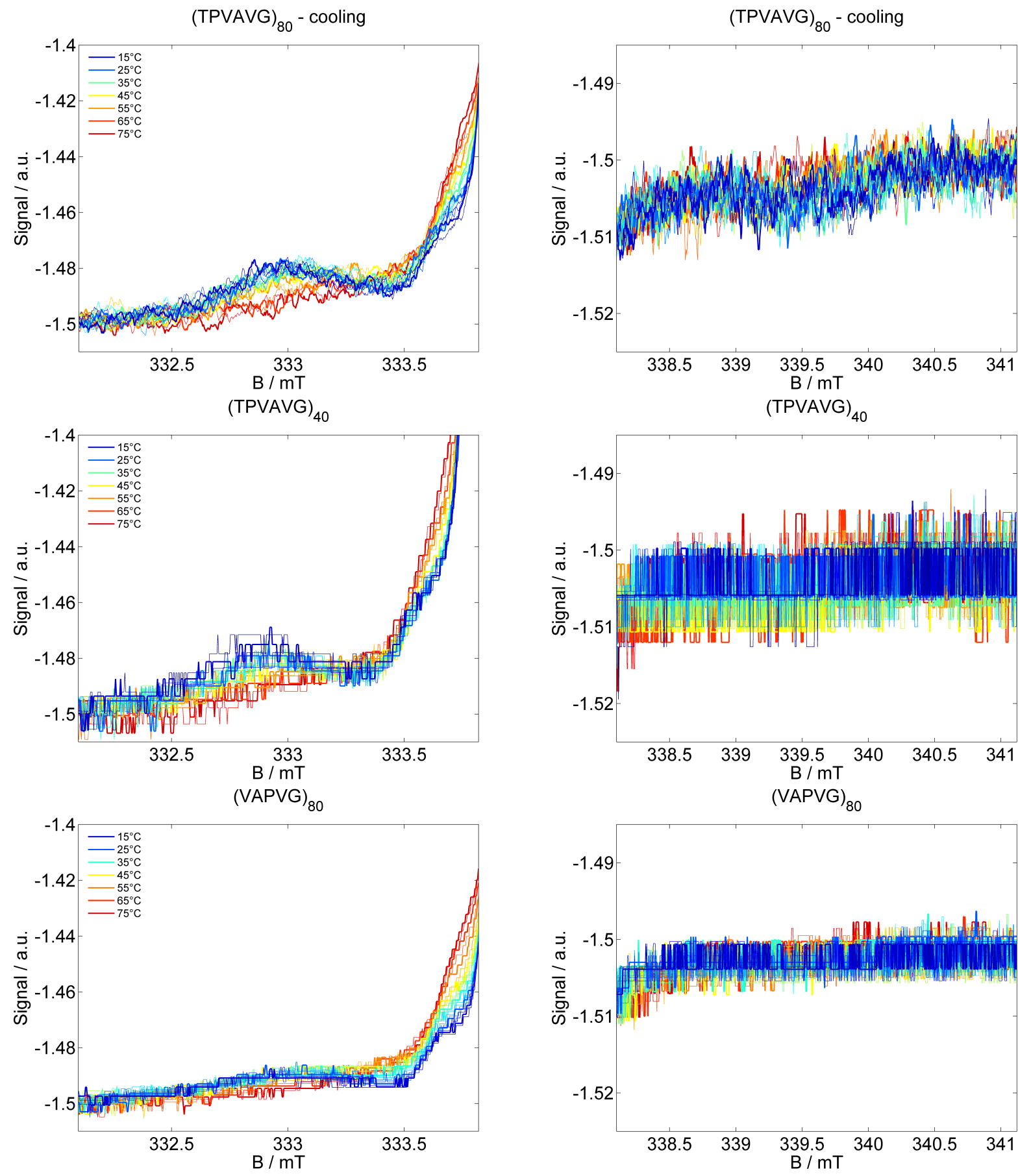

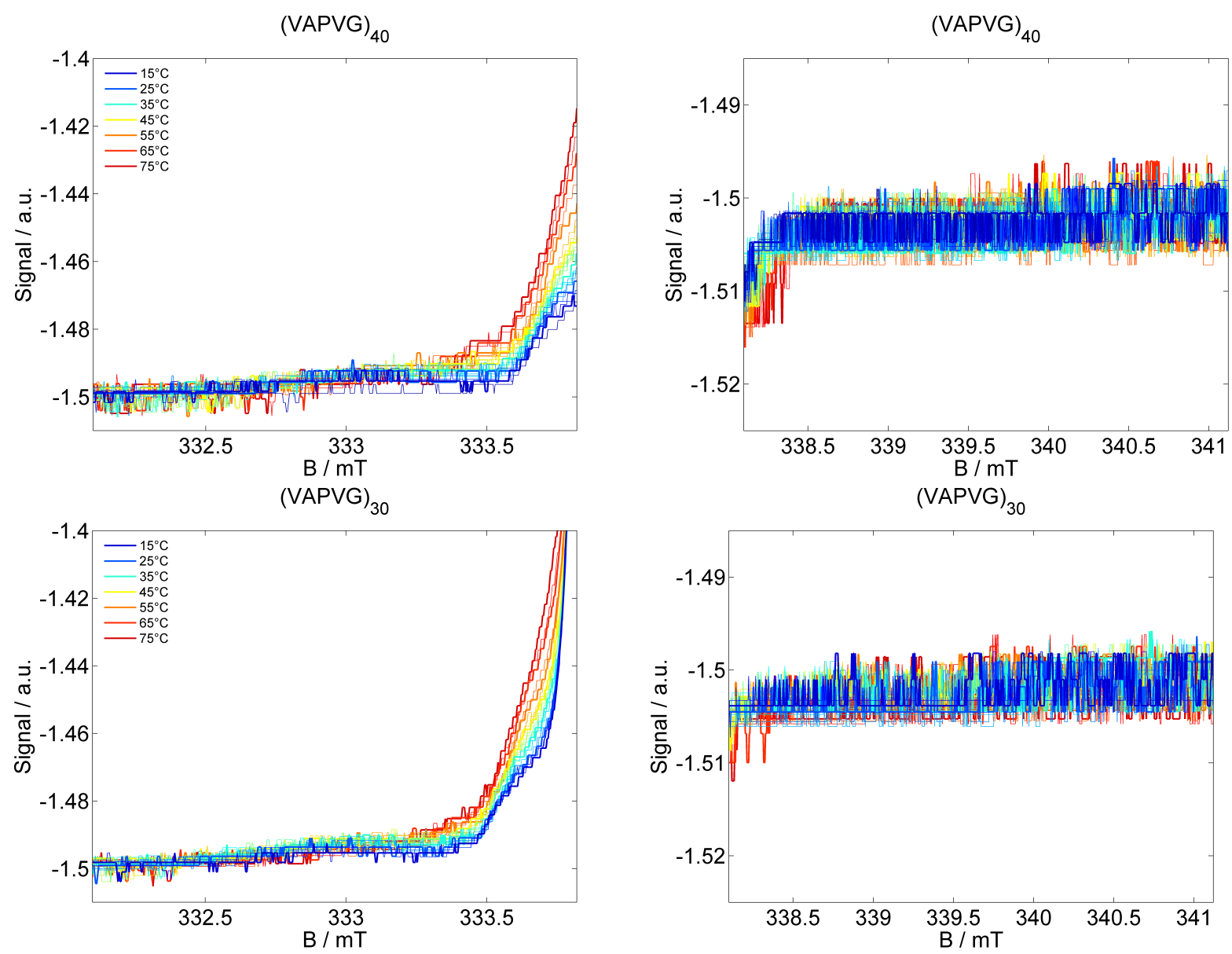

Figure SI 1: Low (left) and high (right) field lines of the immobile component of the $\mathrm{CW}$ EPR spectra of all polymers 

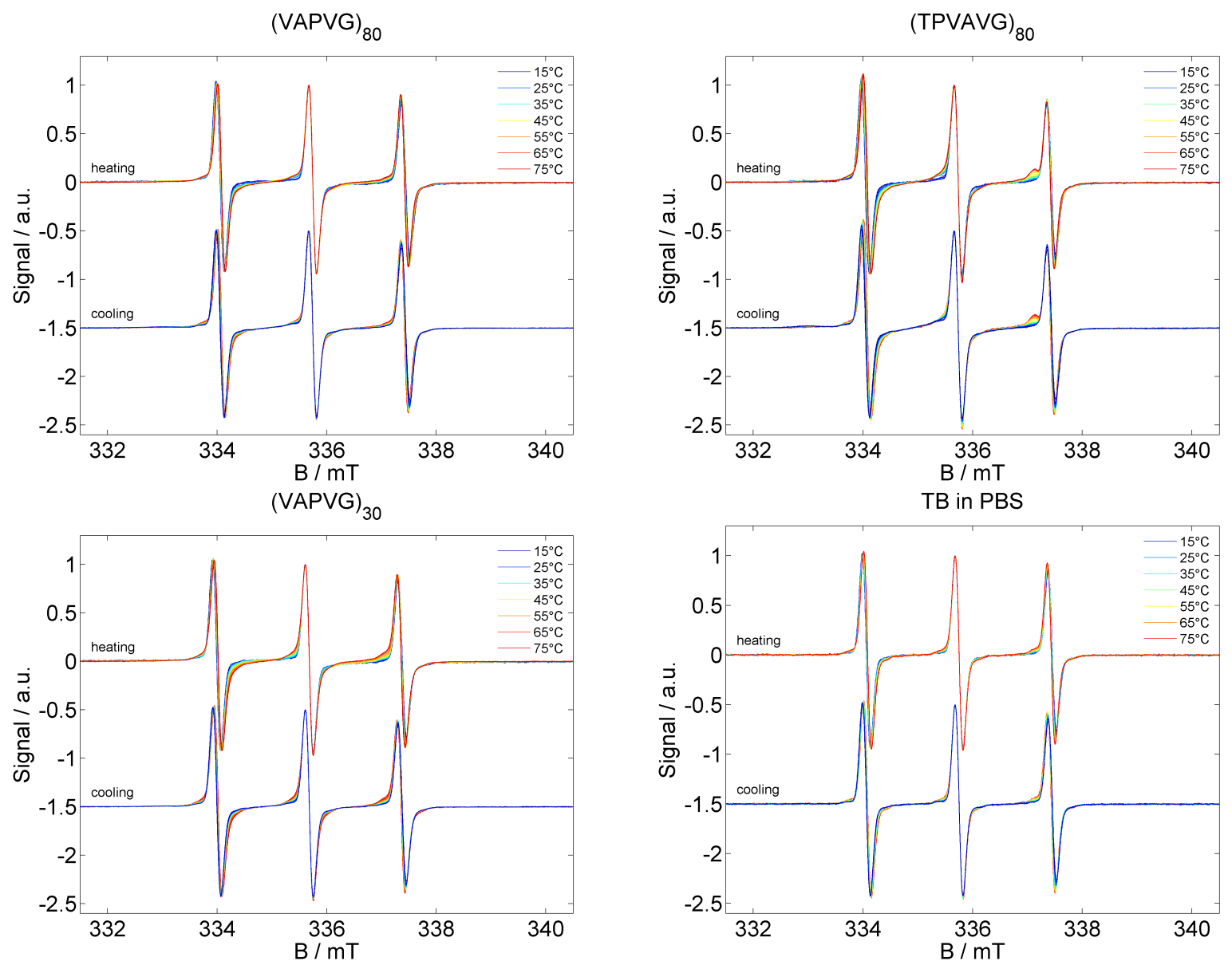

Figure SI 2: CW EPR spectra of TB in a polymer buffer solution and reference spectra of $\mathrm{TB}$ in $\mathrm{PBS}$ 


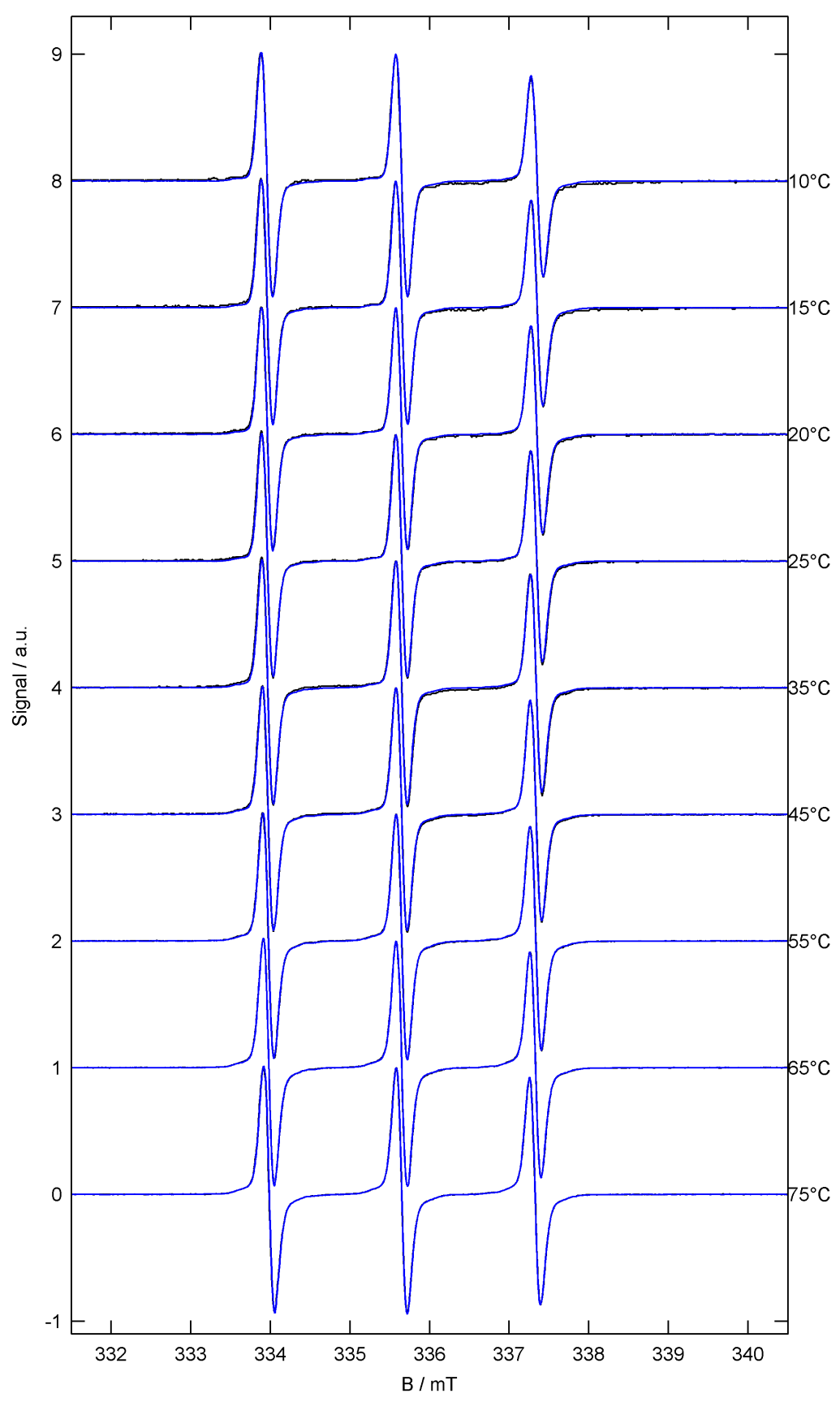

Figure SI3: Superposition of EPR spectra of TB in a buffer solution of (VPGVG) ${ }_{40}(300 \mu \mathrm{M})$ with TB $(1 \mathrm{mM})$ recorded during heating (black) and cooling (blue) at temperatures between 10 and $75^{\circ} \mathrm{C}$. 


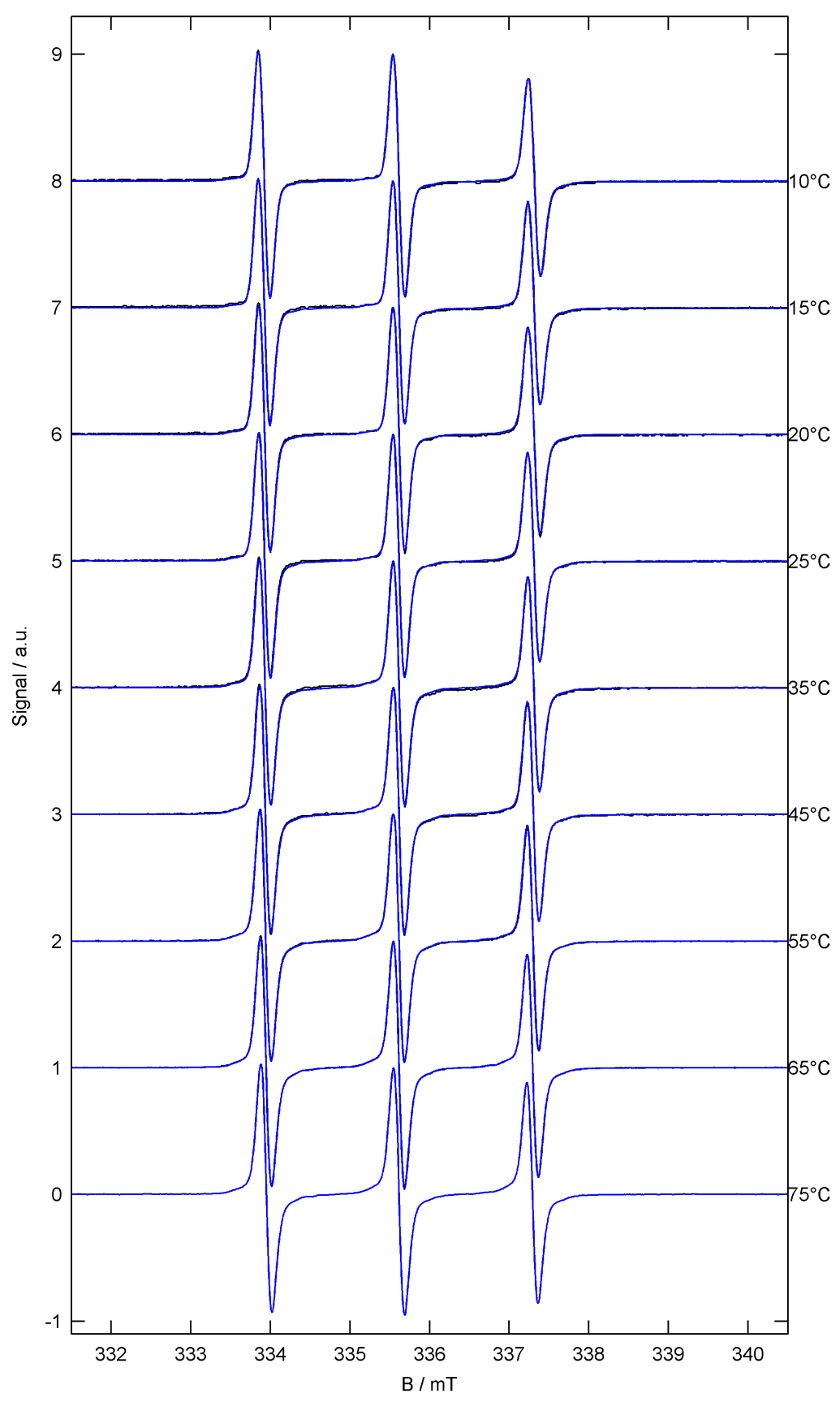

Figure SI4: Superposition of EPR spectra of TB in a buffer solution of (VPGVG) 80 (300 $\mu \mathrm{M})$ with TB $(1 \mathrm{mM})$ recorded during heating (black) and cooling (blue) at temperatures between 10 and $75^{\circ} \mathrm{C}$. 

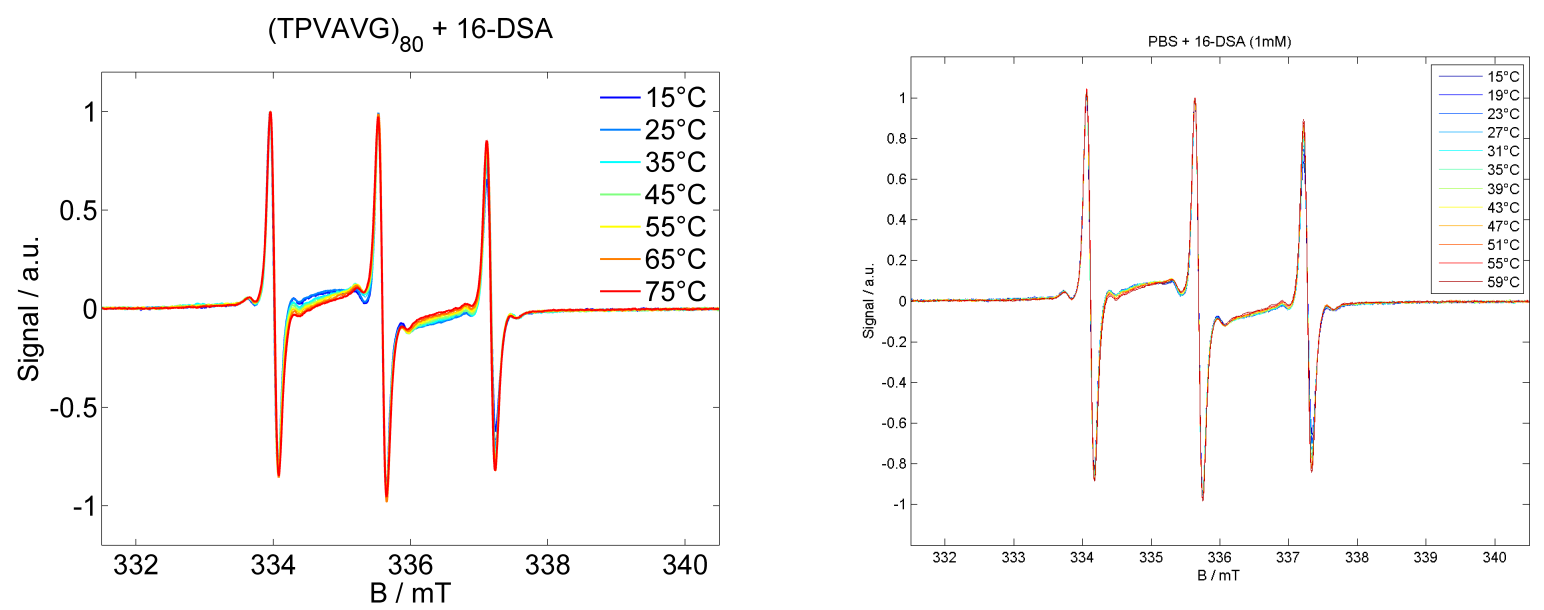

Figure SI 5: CW EPR spectra of 16-DSA $(1 \mathrm{mM})$ in a (TPVAVG) ${ }_{80}$ buffer solution $(300 \mu \mathrm{M})$ and reference spectra of 16-DSA (1 mM) in PBS. 

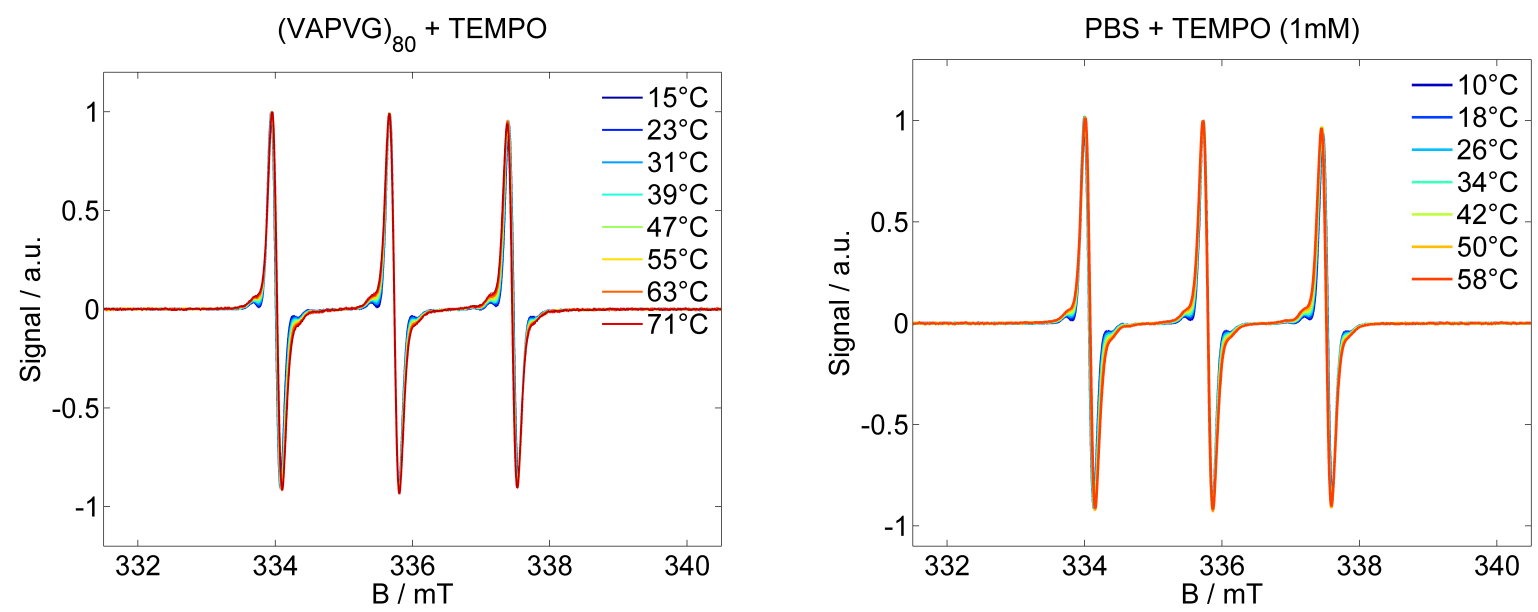

Figure SI6: CW EPR spectra of TEMPO $(400 \mu \mathrm{M})$ in a (VAPVG) ${ }_{80}$ buffer solution $(200 \mu \mathrm{M})$ and reference spectra of TEMPO $(1 \mathrm{mM})$ in PBS.
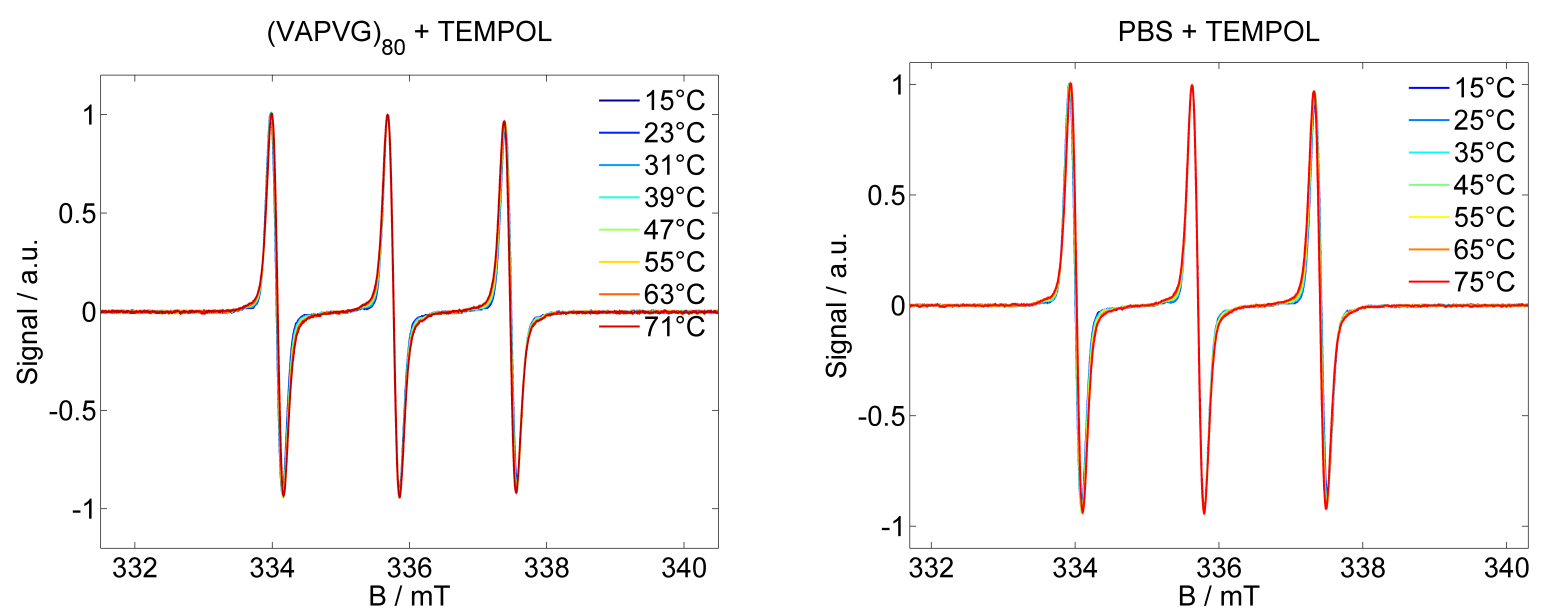

Figure SI 7: CW EPR spectra of TEMPOL $(400 \mu \mathrm{M})$ in a (VAPVG) 80 buffer solution $(200 \mu \mathrm{M})$ and reference spectra of TEMPOL $(1 \mathrm{mM})$ in PBS. 

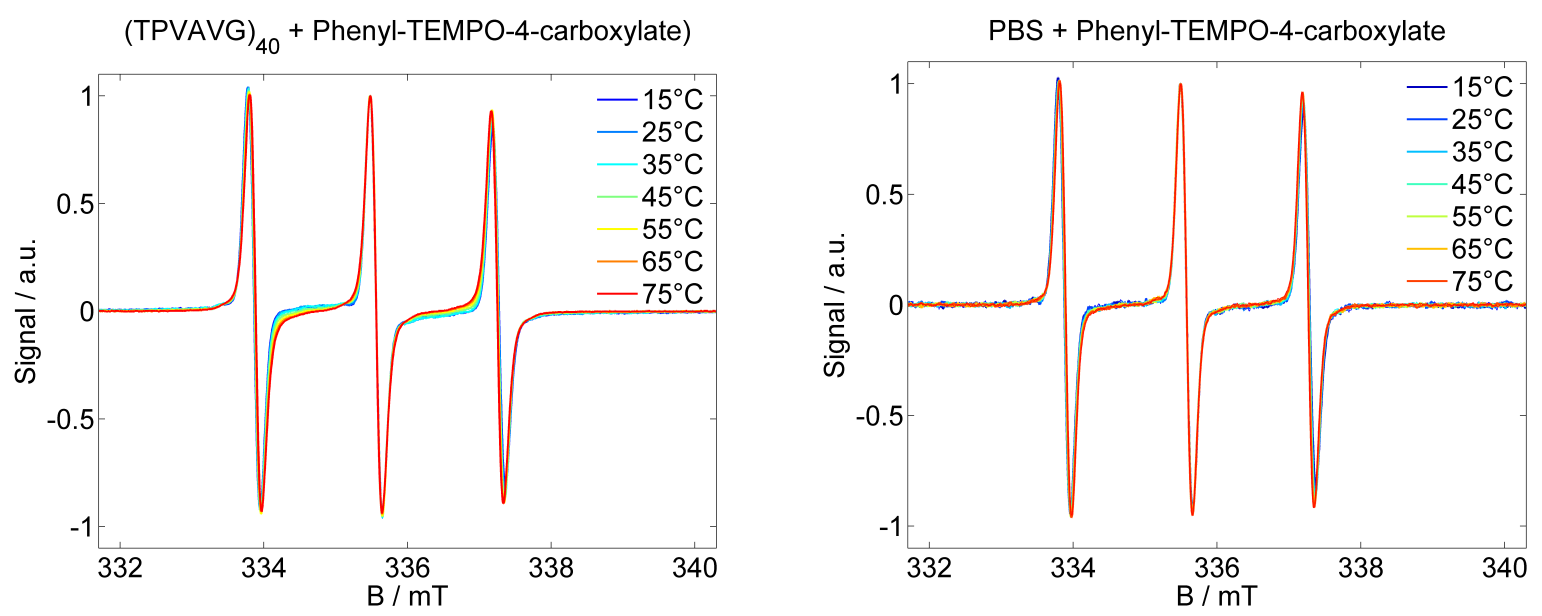

Figure SI 8: CW EPR spectra of Phenyl-TEMPO-4-carboxylate (for chemical structure, see Figure SI 11) $(1 \mathrm{mM})$ in a (TPVAVG) 40 buffer solution $(300 \mu \mathrm{M})$ and reference spectra of Phenyl-TEMPO-4-carboxylate $(1 \mathrm{mM})$ in PBS.
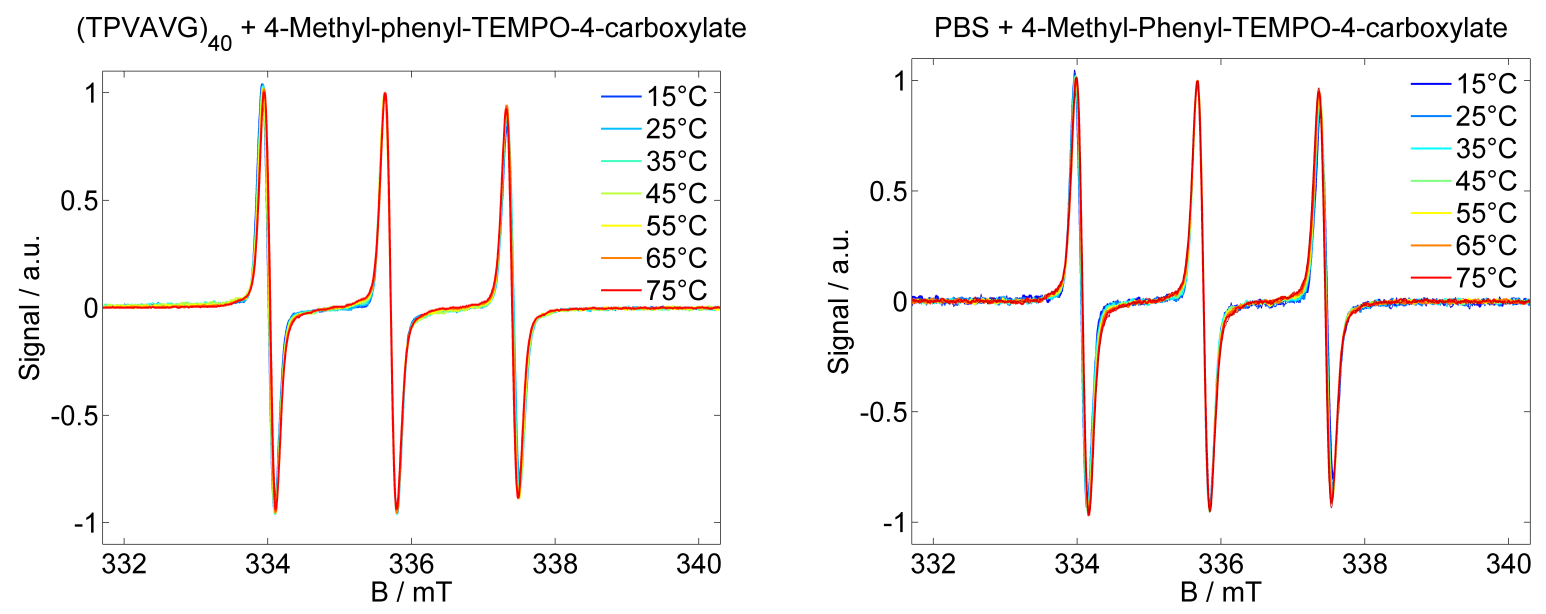

Figure SI9: CW EPR spectra of 4-Methyl-phenyl-TEMPO-4-carboxylate (for chemical structure, see Figure SI 11) $(1 \mathrm{mM})$ in a (TPVAVG) $)_{40}$ buffer solution $(300 \mu \mathrm{M})$ and reference spectra of 4-Methyl-phenyl-TEMPO-4-carboxylate (1 mM) in PBS. 

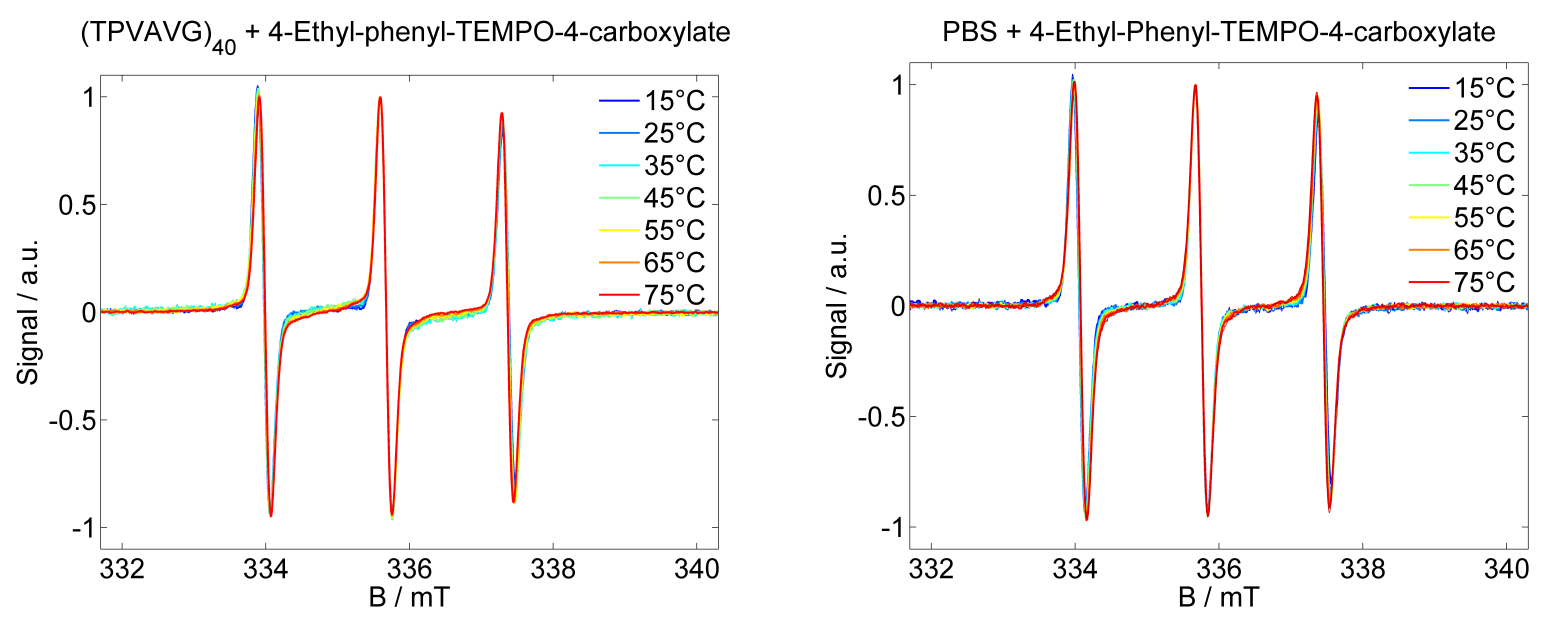

Figure SI10: CW EPR spectra of 4-Ethyl-phenyl-TEMPO-4-carboxylate (for chemical structure, see Figure SI 11) $(1 \mathrm{mM})$ in a (TPVAVG) $)_{40}$ buffer solution $(300 \mu \mathrm{M})$ and reference spectra of 4-Ethyl-phenyl-TEMPO-4-carboxylate $(1 \mathrm{mM})$ in PBS.
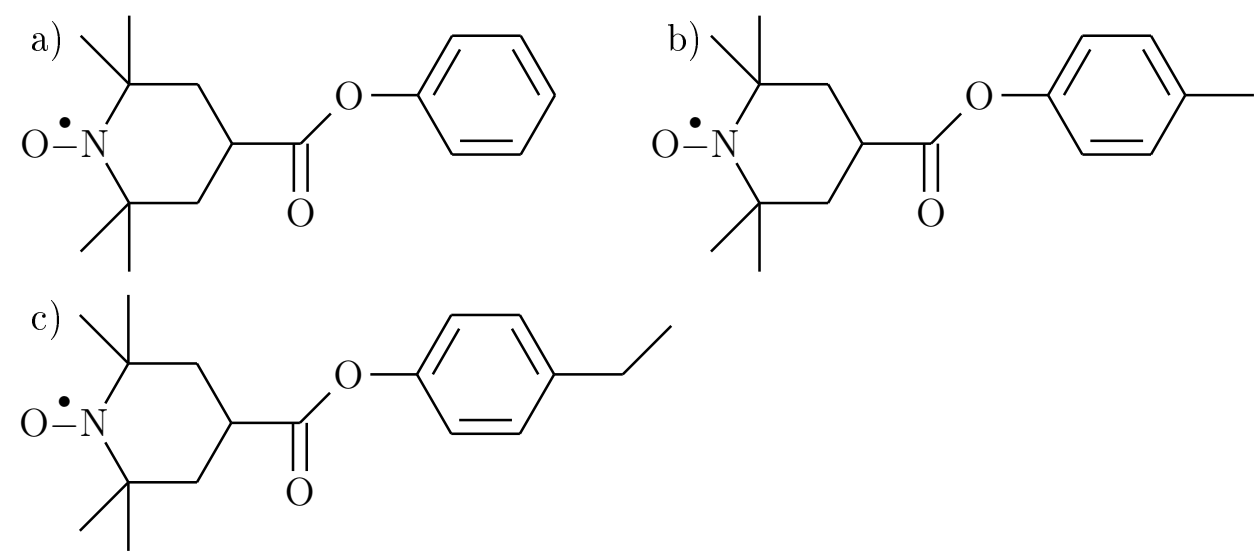

Figure SI 11: Structural formula of a) Phenyl-TEMPO-4-carboxylate, b) 4-Methyl-phenylTEMPO-4-carboxylate and c) 4-Ethyl-phenyl-TEMPO-4-carboxylate.
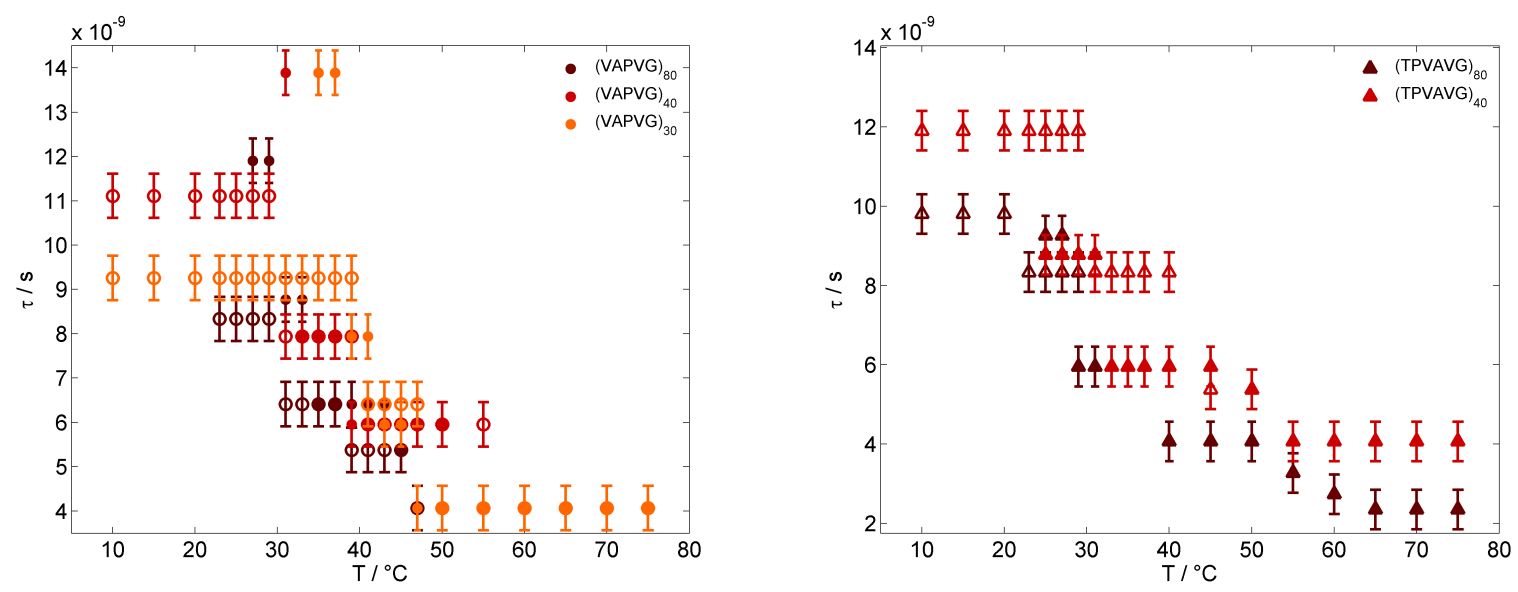

Figure SI 12: Rotational correlation times of the simulated immobile component compared for same motif (left: (VAPVG) and right: (TPVAVG)) 

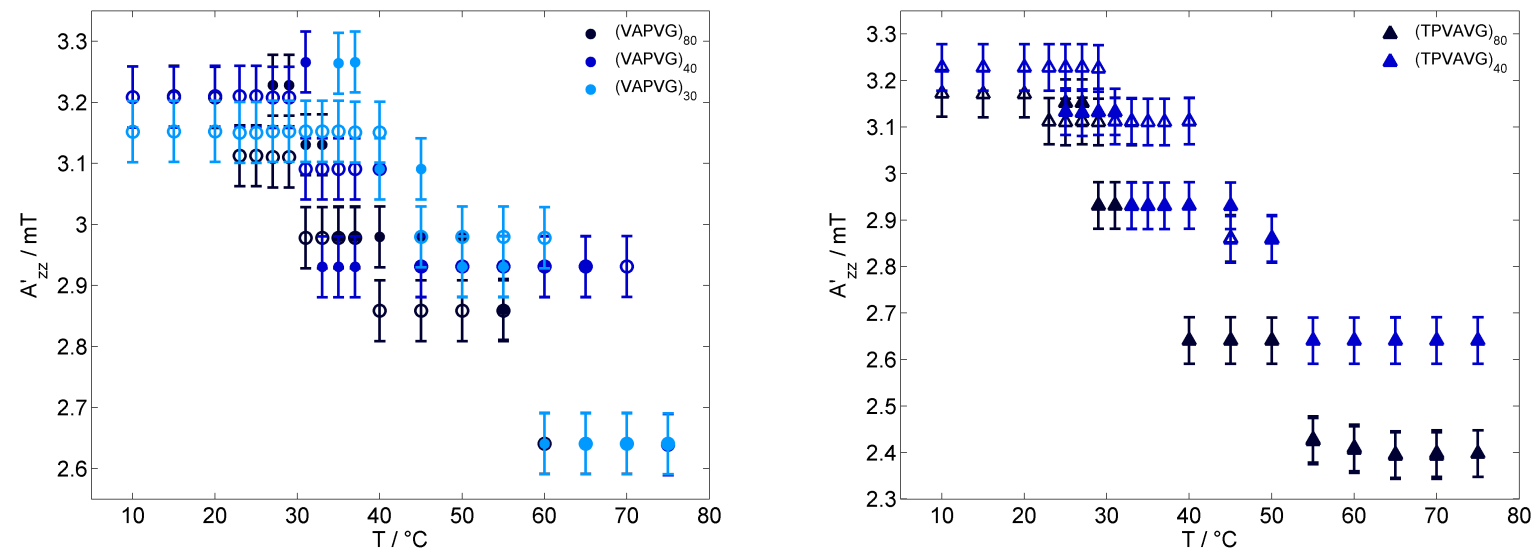

Figure SI 13: Hyperfine splitting constants of the simulated immobile component compared for same motif (left: (VAPVG) and right: (TPVAVG))

(a)

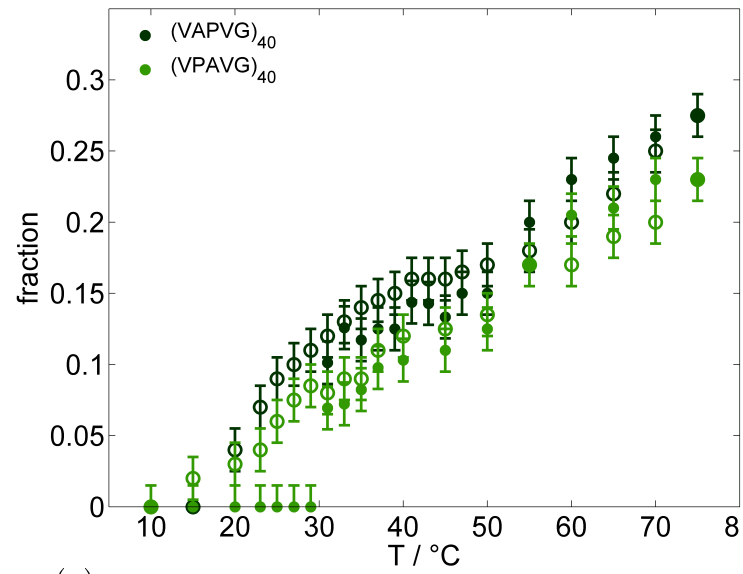

(c)

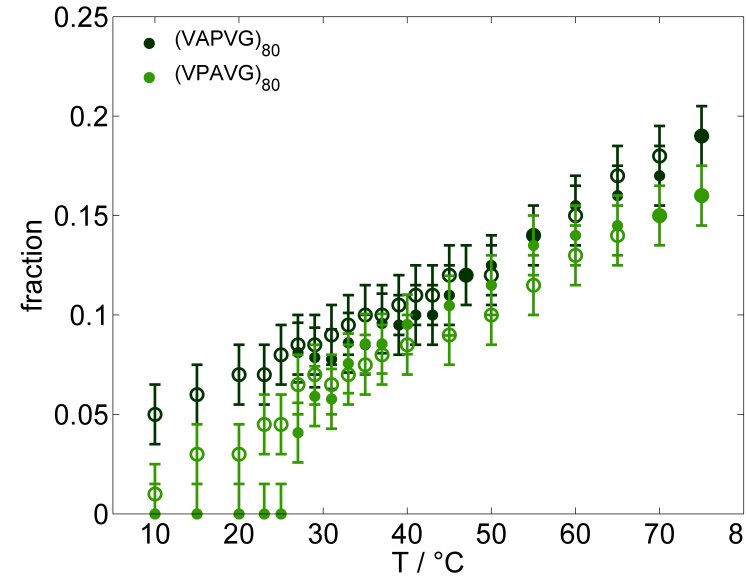

(b)

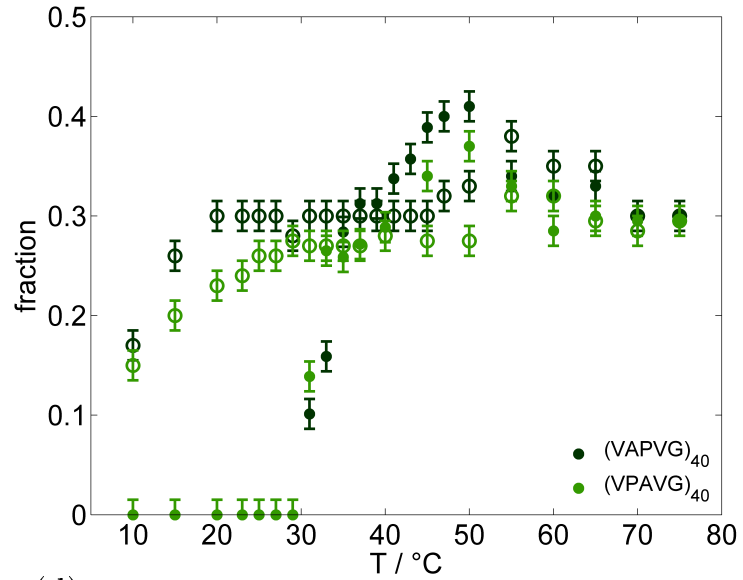

(d)

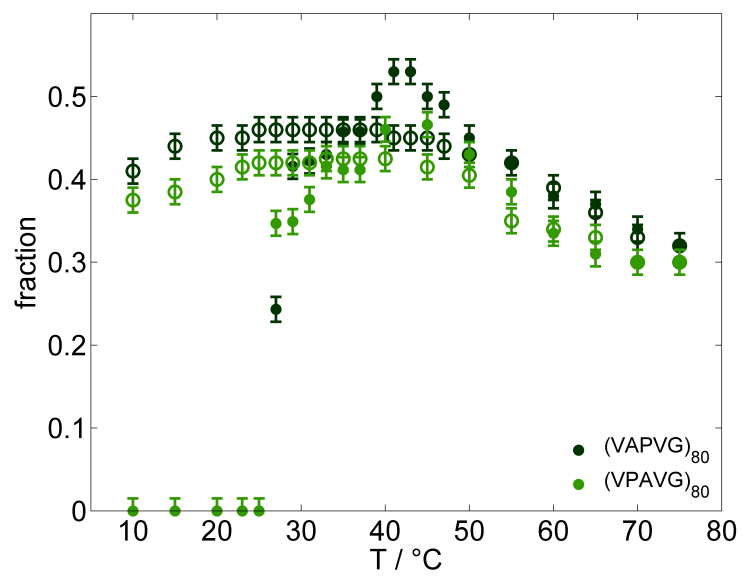

Figure SI 14: Fractions of the components of the EPR spectra of the (VAPVG) $n$ and $(\mathrm{VPAVG})_{n}$ polymers arising with the transition of the polymer from rigorous spectral simulation. a), c) Fractions of the hydrophobic component, b), d) fractions of the immobile component, • heating and o cooling. 

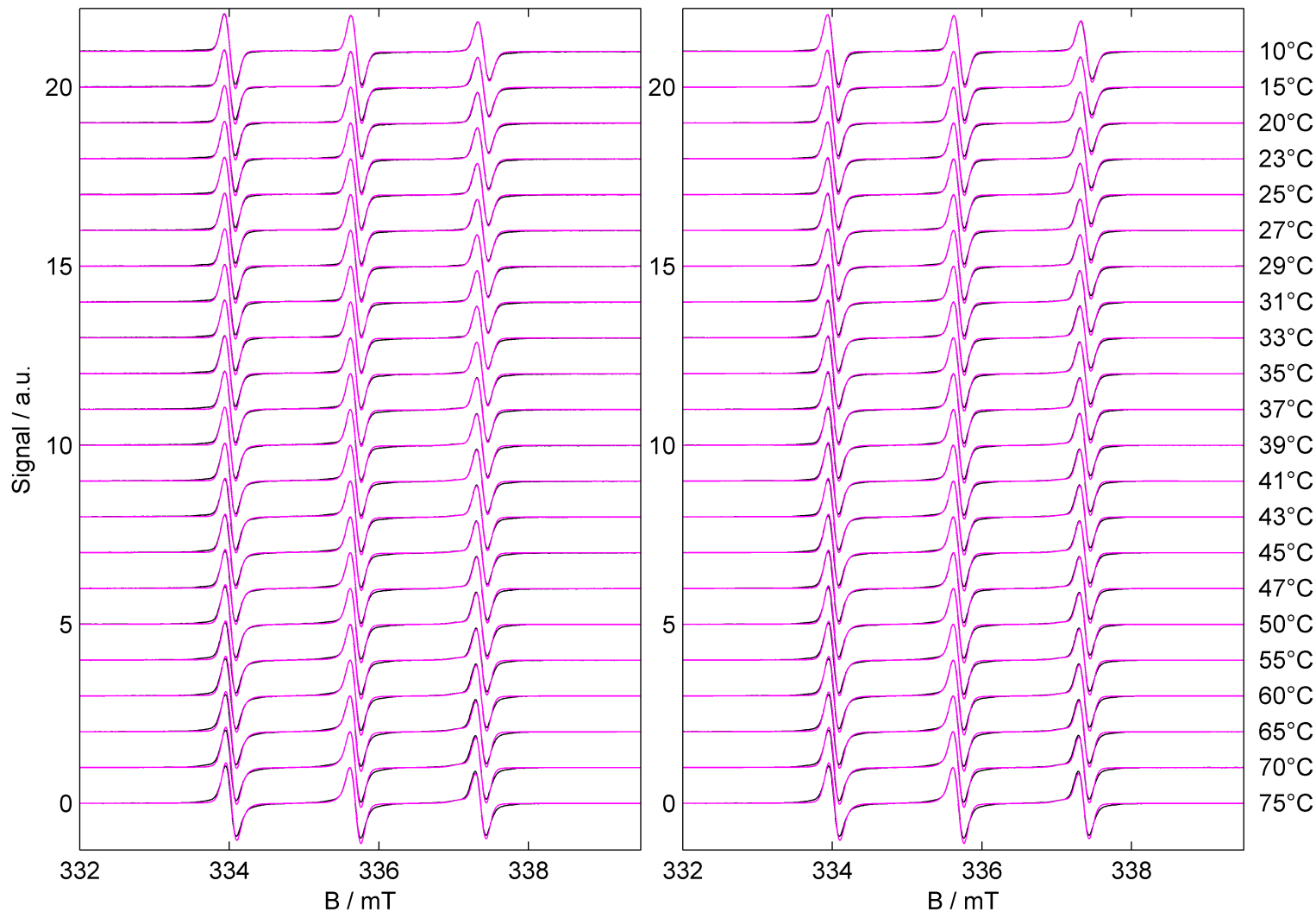

Figure SI 15: All EPR spectral simulations of (VAPVG) $)_{30}(300 \mu \mathrm{M})$ with TB $(1 \mathrm{mM})$ at temperatures between 10 and $75^{\circ} \mathrm{C}$, heating (left) and cooling (right). Experimental data is shown in black, simulated data in magenta.
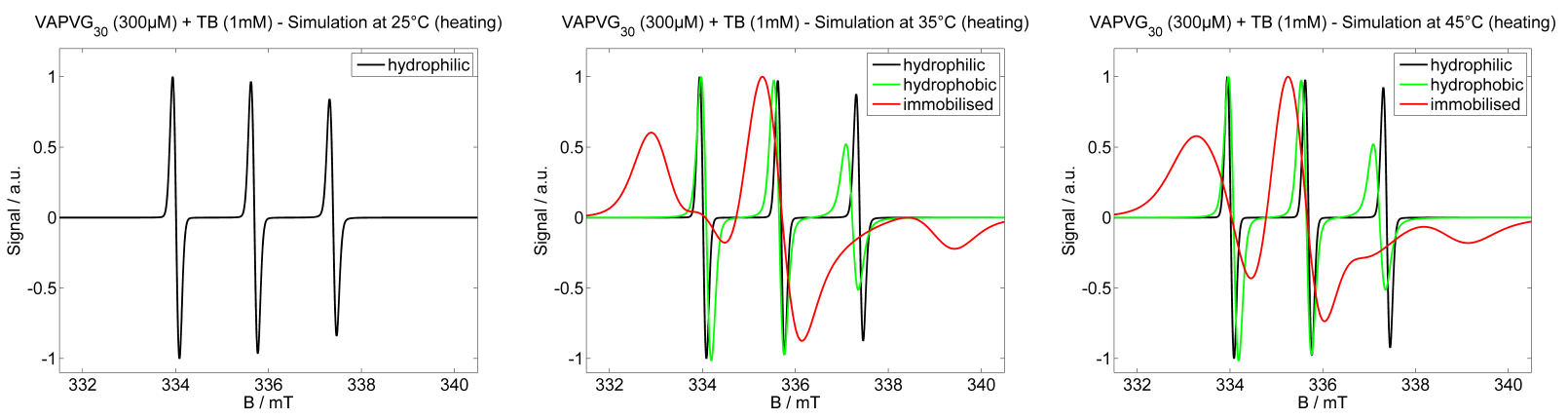

Figure SI 16: Simulated EPR spectroscopical components of (VAPVG) $)_{30}(300 \mu \mathrm{M})$ with TB $(1 \mathrm{mM})$ at a temperature before $\left(25^{\circ} \mathrm{C}\right)$, near $\left(35^{\circ} \mathrm{C}\right)$ at after $\left(45^{\circ} \mathrm{C}\right)$ transition. 

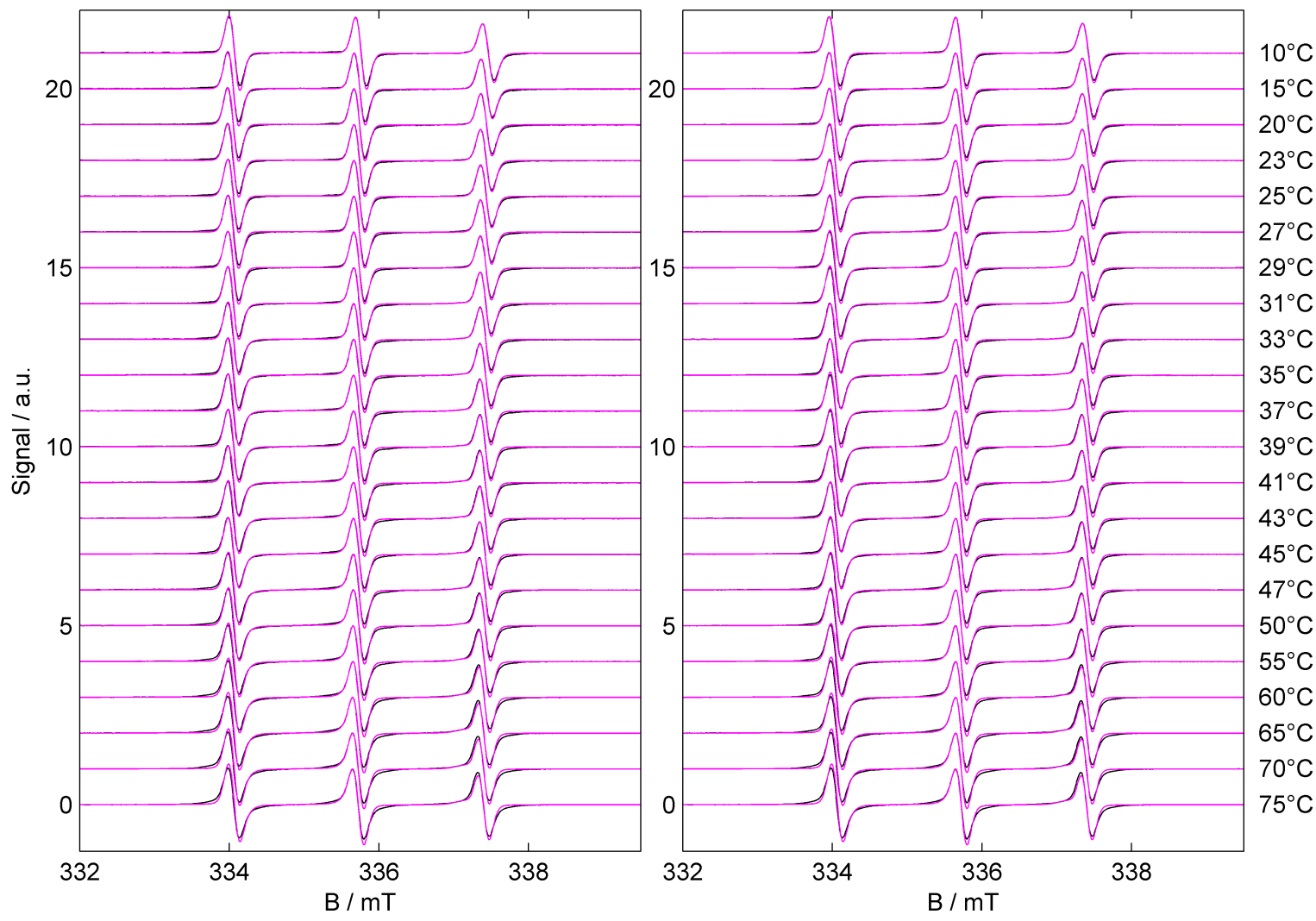

Figure SI 17: All EPR spectral simulations of (VAPVG) $40(300 \mu \mathrm{M})$ with TB $(1 \mathrm{mM})$ at temperatures between 10 and $75^{\circ} \mathrm{C}$, heating (left) and cooling (right). Experimental data is shown in black, simulated data in magenta.
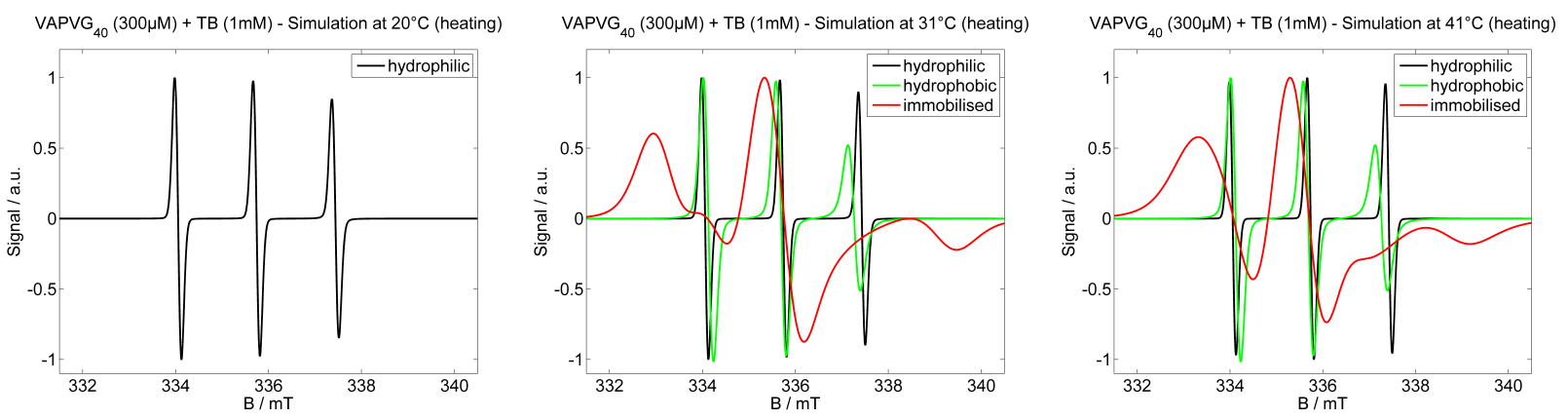

Figure SI 18: Simulated EPR spectroscopical components of (VAPVG) $)_{40}(300 \mu \mathrm{M})$ with TB $(1 \mathrm{mM})$ at a temperature before $\left(20^{\circ} \mathrm{C}\right)$, near $\left(31^{\circ} \mathrm{C}\right)$ at after $\left(41^{\circ} \mathrm{C}\right)$ transition. 

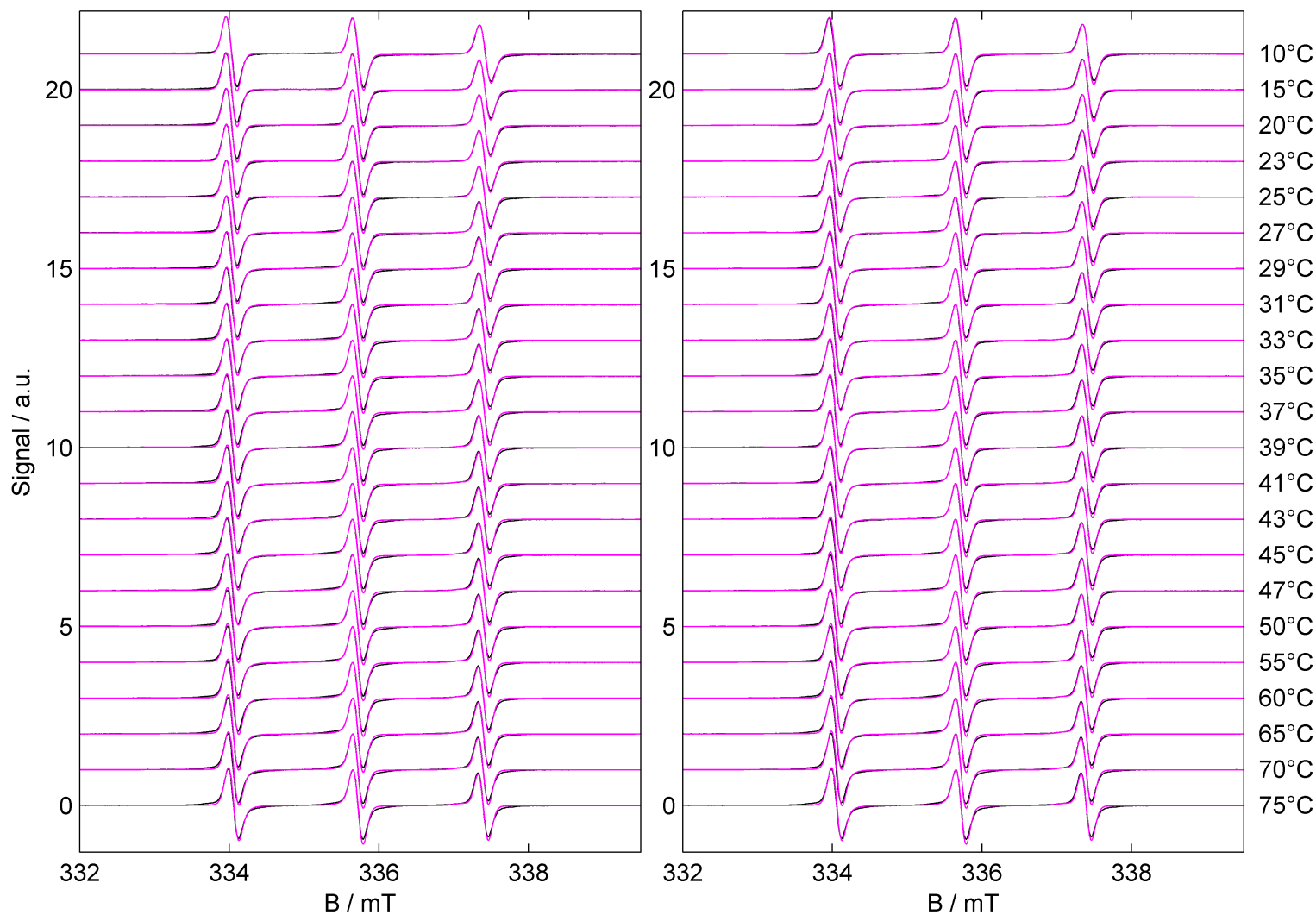

Figure SI 19: All EPR spectral simulations of (VAPVG) $)_{80}(300 \mu \mathrm{M})$ with TB $(1 \mathrm{mM})$ at temperatures between 10 and $75^{\circ} \mathrm{C}$, heating (left) and cooling (right). Experimental data is shown in black, simulated data in magenta.
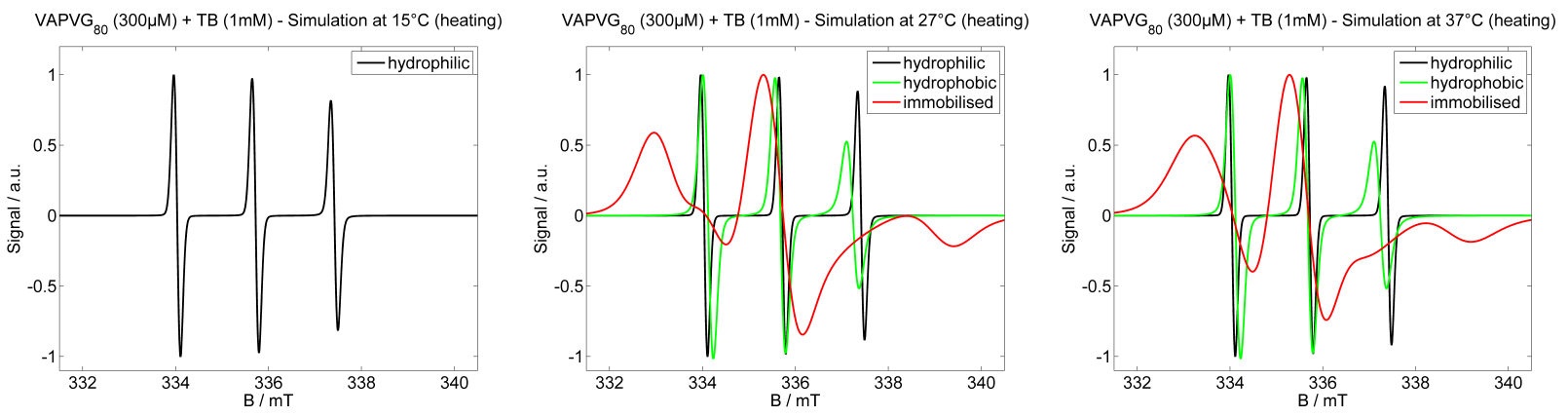

Figure SI 20: Simulated EPR spectroscopical components of (VAPVG) $)_{80}(300 \mu \mathrm{M})$ with TB $(1 \mathrm{mM})$ at a temperature before $\left(15^{\circ} \mathrm{C}\right)$, near $\left(27^{\circ} \mathrm{C}\right)$ at after $\left(37^{\circ} \mathrm{C}\right)$ transition. 

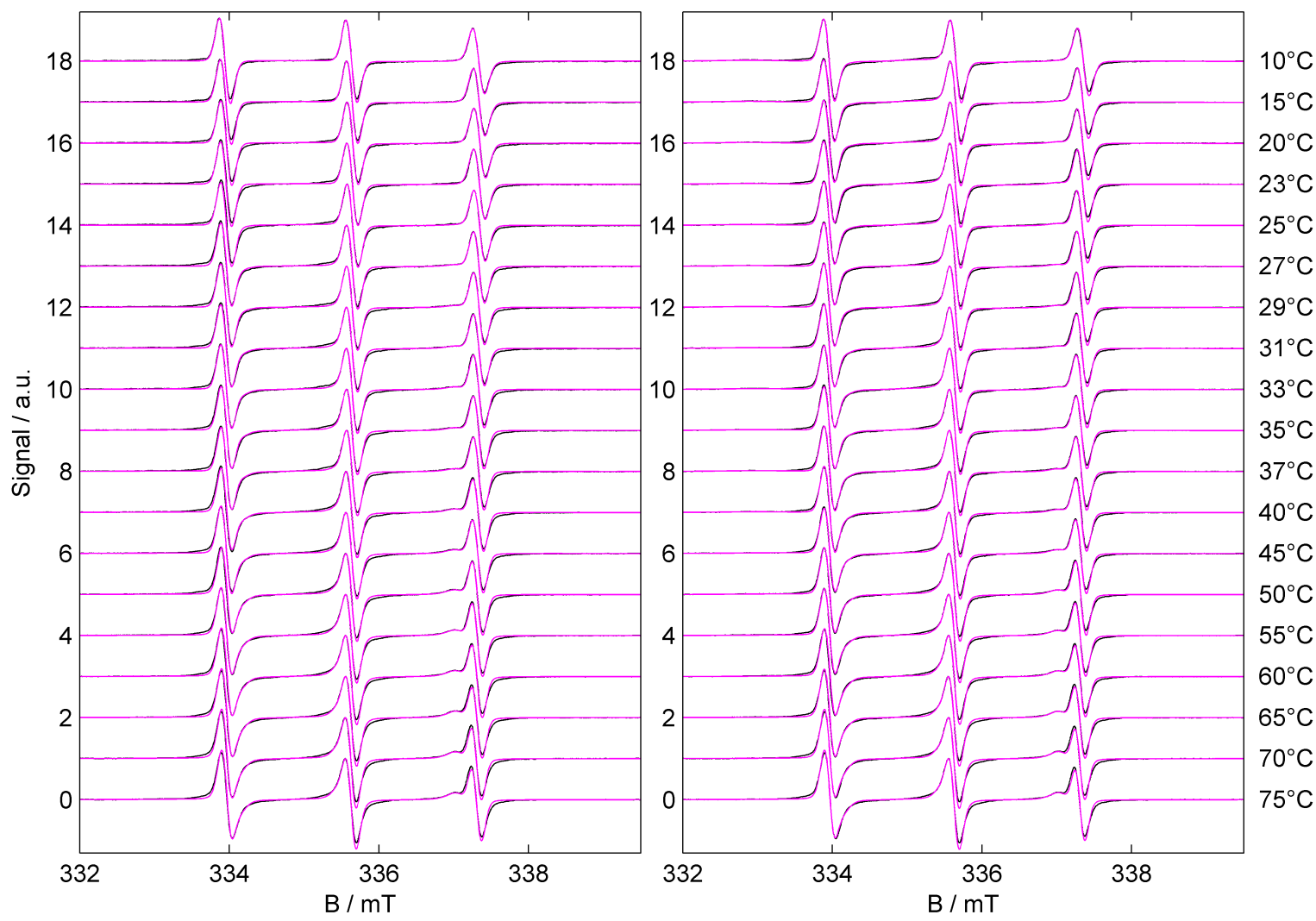

Figure SI 21: All EPR spectral simulations of (TPVAVG $)_{40}(300 \mu \mathrm{M})$ with TB $(1 \mathrm{mM})$ at temperatures between 10 and $75^{\circ} \mathrm{C}$, heating (left) and cooling (right). Experimental data is shown in black, simulated data in magenta.
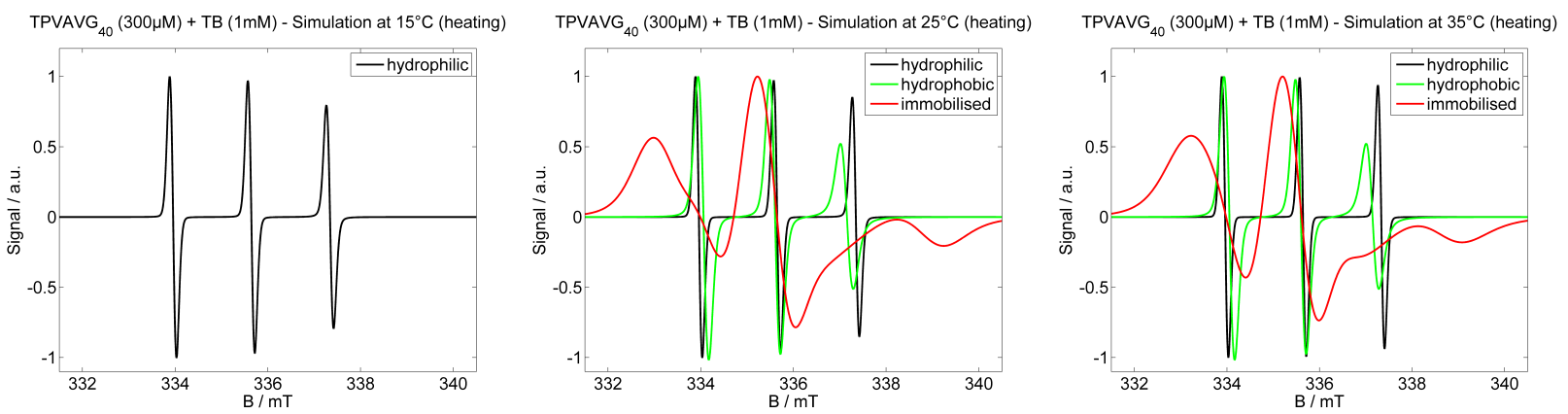

Figure SI 22: Simulated EPR spectroscopical components of (TPVAVG) $40(300 \mu \mathrm{M})$ with $\mathrm{TB}(1 \mathrm{mM})$ at a temperature before $\left(15^{\circ} \mathrm{C}\right)$, near $\left(25^{\circ} \mathrm{C}\right)$ at after $\left(35^{\circ} \mathrm{C}\right)$ transition. 

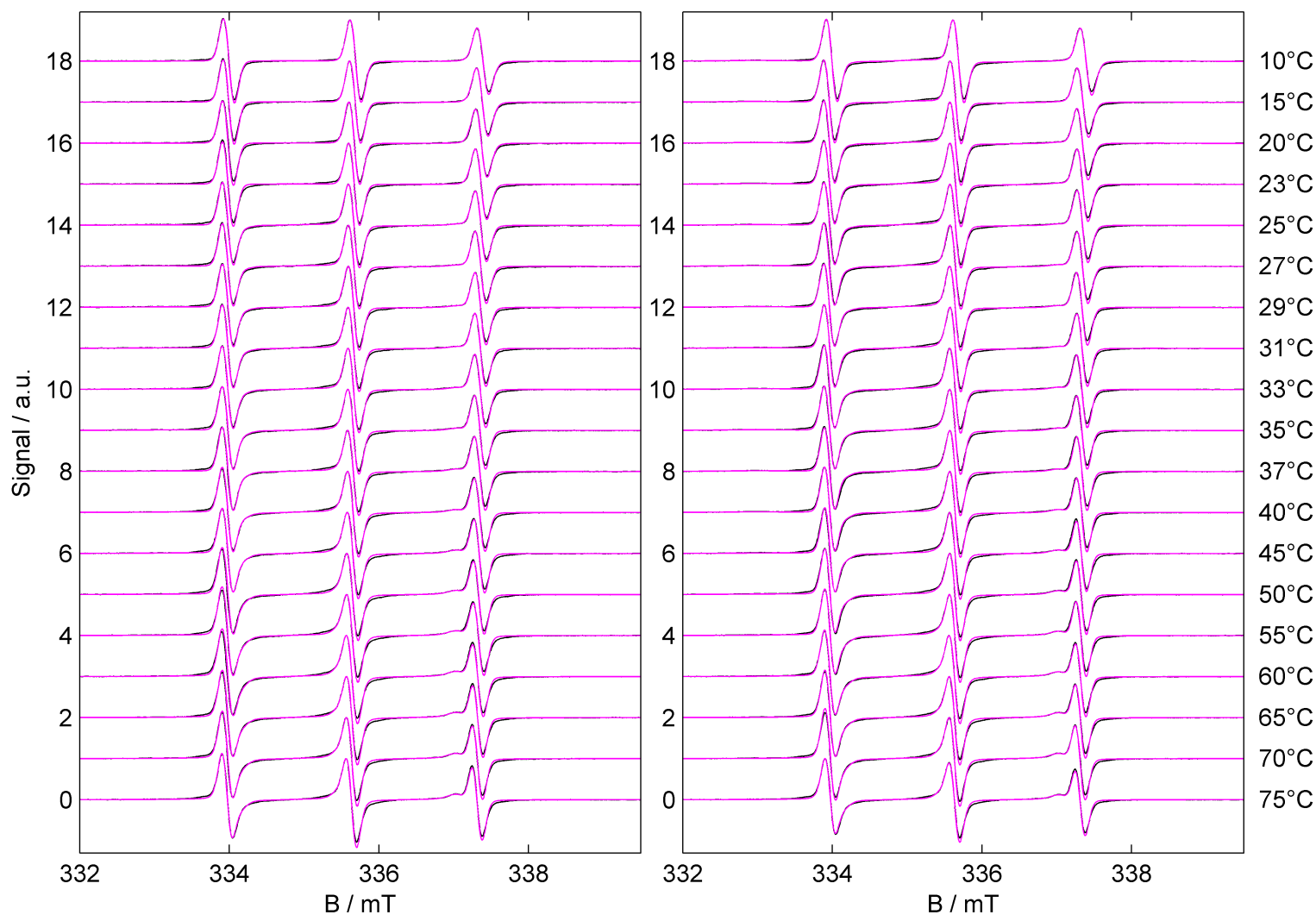

Figure SI 23: All EPR spectral simulations of (TPVAVG) $)_{80}(300 \mu \mathrm{M})$ with TB $(1 \mathrm{mM})$ at temperatures between 10 and $75^{\circ} \mathrm{C}$, heating (left) and cooling (right). Experimental data is shown in black, simulated data in magenta.
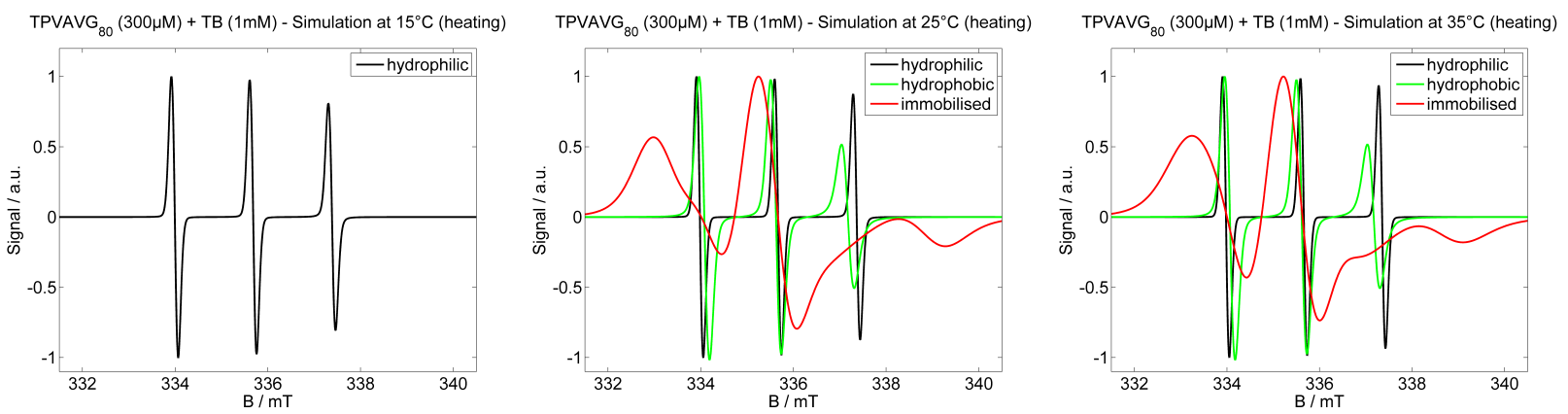

Figure SI 24: Simulated EPR spectroscopical components of (TPVAVG) $80(300 \mu \mathrm{M})$ with $\mathrm{TB}(1 \mathrm{mM})$ at a temperature before $\left(15^{\circ} \mathrm{C}\right)$, near $\left(25^{\circ} \mathrm{C}\right)$ at after $\left(35^{\circ} \mathrm{C}\right)$ transition. 

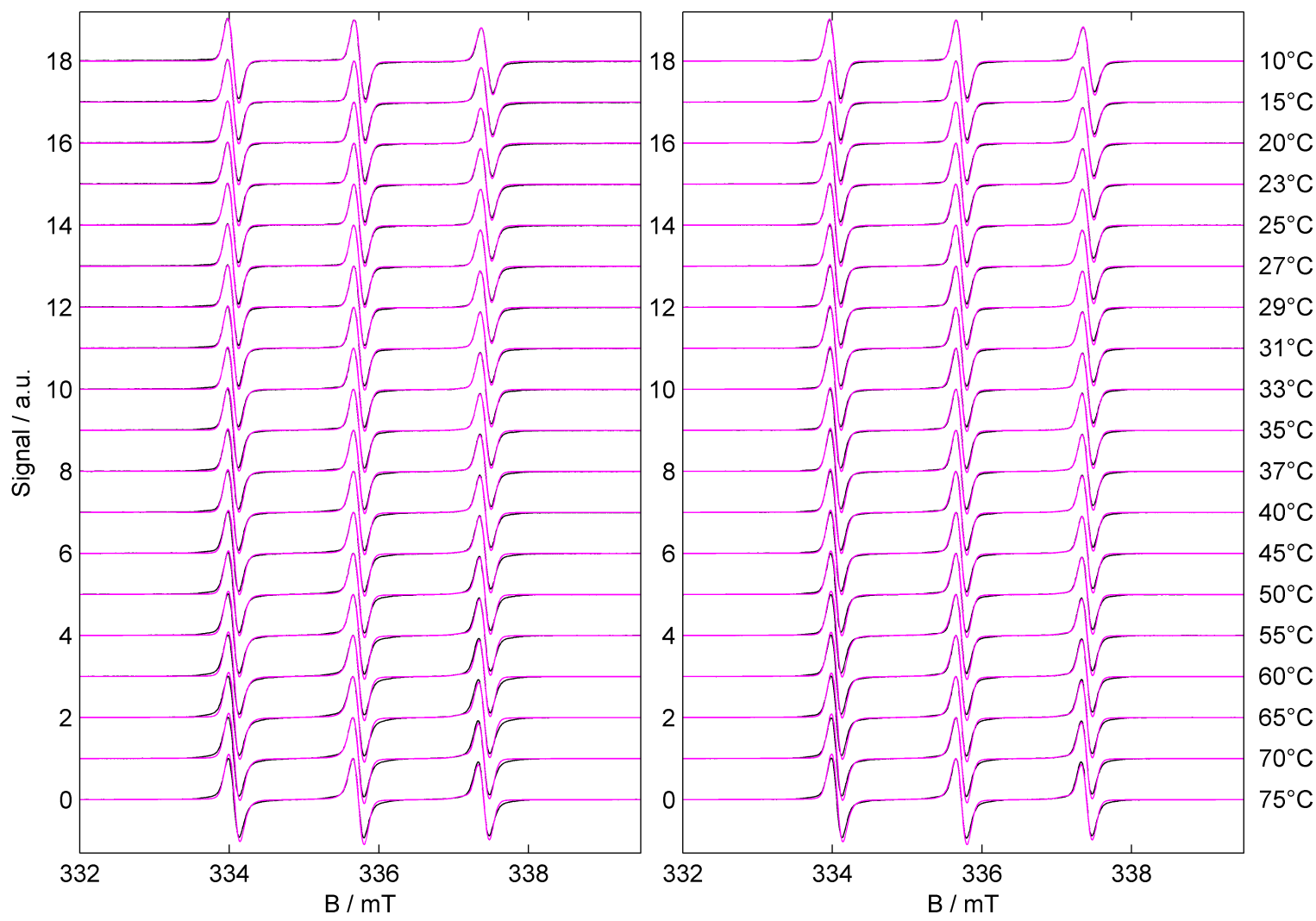

Figure SI 25: All EPR spectral simulations of (VPAVG) $)_{40}(300 \mu \mathrm{M})$ with $\mathrm{TB}(1 \mathrm{mM})$ at temperatures between 10 and $75^{\circ} \mathrm{C}$, heating (left) and cooling (right). Experimental data is shown in black, simulated data in magenta.
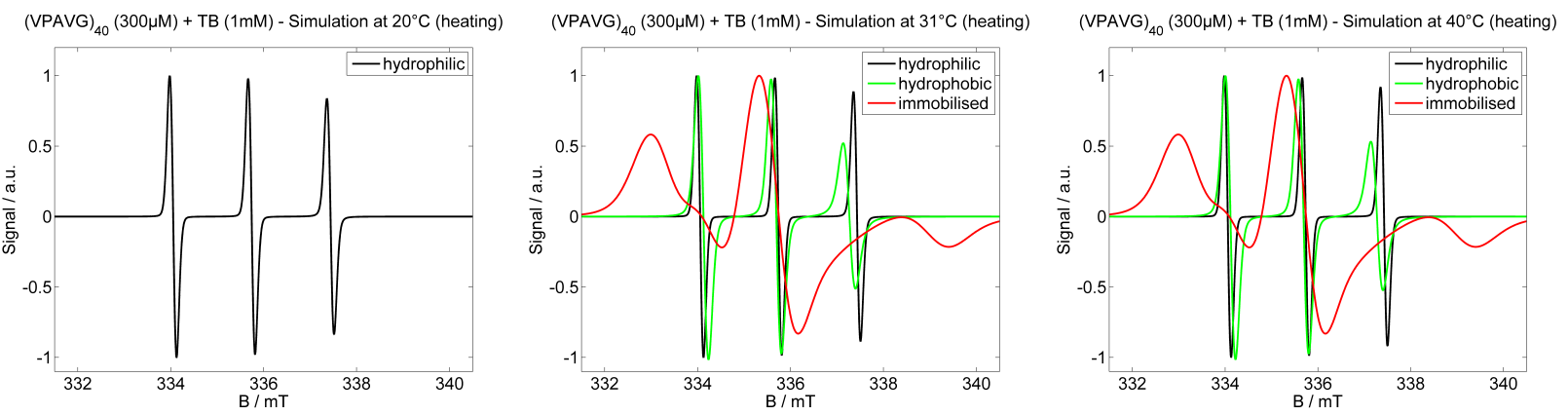

Figure SI 26: Simulated EPR spectroscopical components of (VPAVG) $40(300 \mu \mathrm{M})$ with TB $(1 \mathrm{mM})$ at a temperature before $\left(20^{\circ} \mathrm{C}\right)$, near $\left(31^{\circ} \mathrm{C}\right)$ at after $\left(40^{\circ} \mathrm{C}\right)$ transition. 

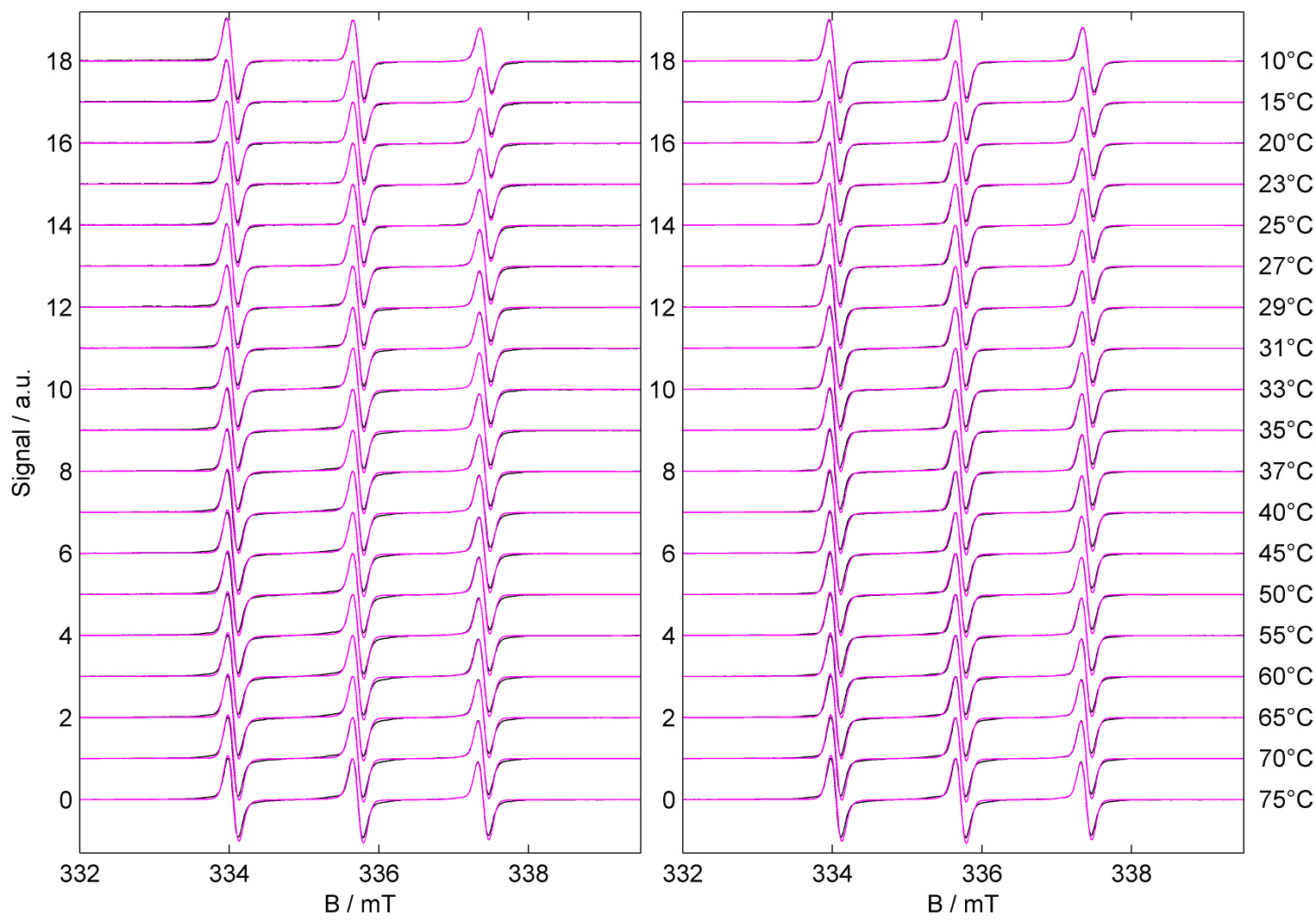

Figure SI 27: All EPR spectral simulations of (VPAVG) $)_{80}(300 \mu \mathrm{M})$ with $\mathrm{TB}(1 \mathrm{mM})$ at temperatures between 10 and $75^{\circ} \mathrm{C}$, heating (left) and cooling (right). Experimental data is shown in black, simulated data in magenta.
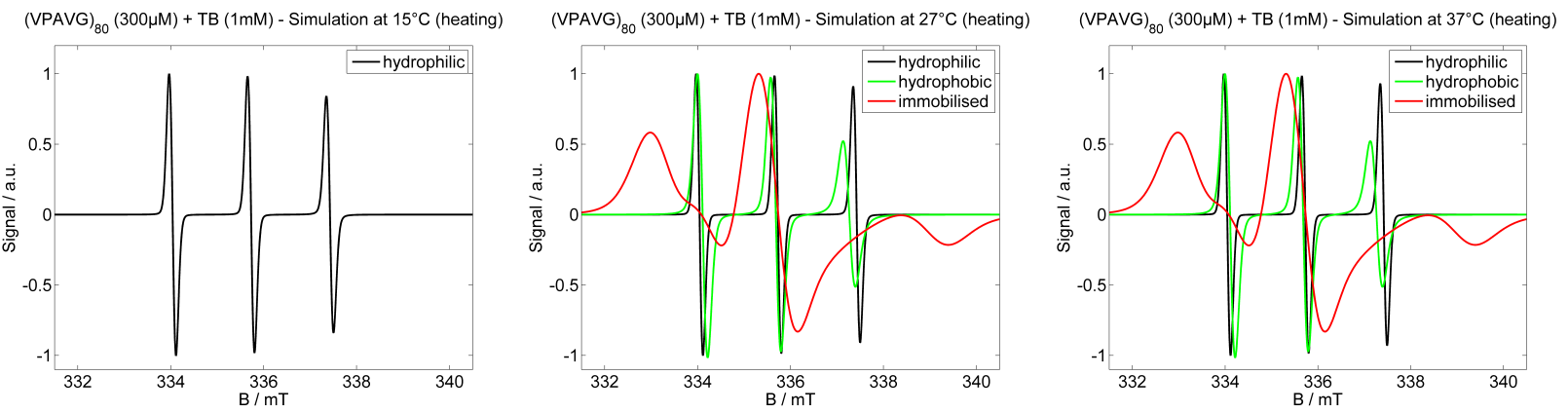

Figure SI 28: Simulated EPR spectroscopical components of (VPAVG) 80 (300 $\mu \mathrm{M})$ with TB $(1 \mathrm{mM})$ at a temperature before $\left(15^{\circ} \mathrm{C}\right)$, near $\left.27^{\circ} \mathrm{C}\right)$ at after $\left(37^{\circ} \mathrm{C}\right)$ transition. 


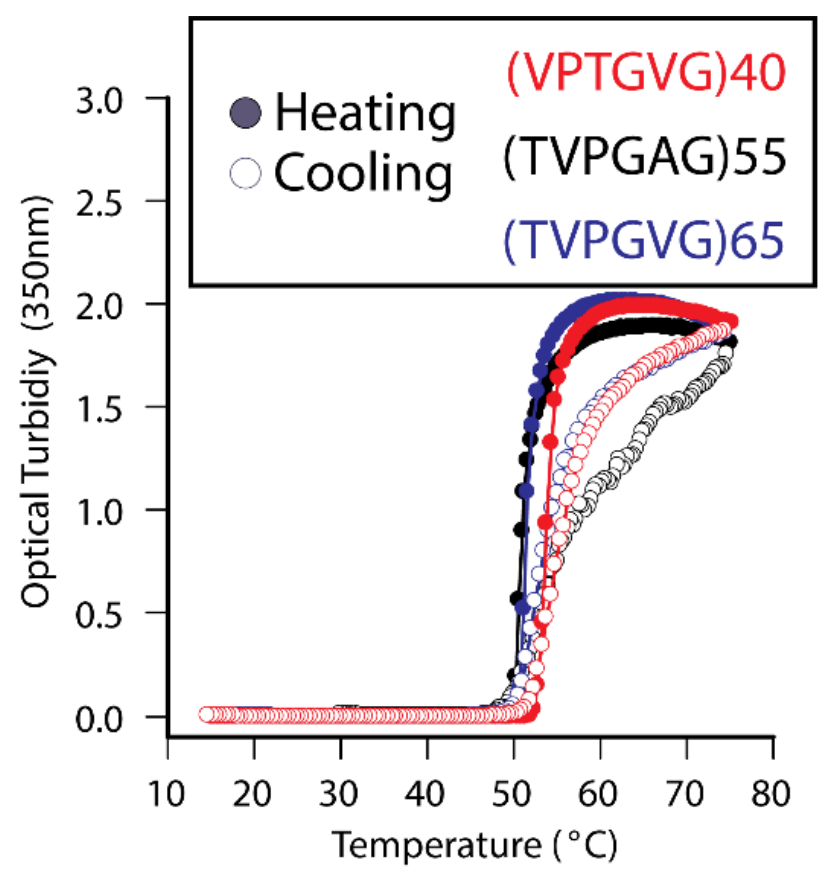

Figure SI 29: Threonine-containing protein-polymers can access non-hysteretic phase behaviours. We show temperature-dependent optical turbidity over a full cycle of heating and cooling pass the cloud point temperature for three intrinsically-disordered protein-polymers. Despite featuring Threonine $(\mathrm{T})$ in their repeat unit, these protein-polymers exhibit fully reversible phase separation behaviour without detectable hysteresis. Optical turbidity measurements were performed at a fixed concentration of $50 \mu \mathrm{M}$ in PBS, with heating and cooling at $1^{\circ} \mathrm{C} / \mathrm{min}$, except for $(\mathrm{TVPGAG})_{55}$. The latter was characterised as indicated but in PBS supplemented with $2 \mathrm{M} \mathrm{NaCl}$. 
We synthesized peptide polymers as previously reported [S1]. Briefly, using a conventional Pre-RDL approach, we synthesized genes encoding 30, 40 and 80 repeats for each peptide motif(VAPVG, TPVAVG, VPGVG and VPAVG). We then added an N-terminal leader peptide, SKGP (to boost expression/yield) [S2] and a Cterminal GWP tripeptide to enable peptide polymer quantification via UV absorption measurements at $280 \mathrm{~nm} . ”$

[S1] Quiroz, F. G.; Li, N. K.; Roberts, S.; Weber, P.; Dzuricky, M.; Weitzhandler, I.; Yingling, Y. G.; Chilkoti, A. Intrinsically disordered proteins access a range of hysteretic phase separation behaviors. Science Advances 2019, 5 .

[S2] Quiroz F. G.; Chilkoti A. "The Language of Protein Polymers." In Sequence-Controlled Polymers: Synthesis, Self-Assembly, and Properties, pp. 15-33. American Chemical Society, 2014. 